sumado a las propiedades táctiles de los materiales y la belleza que inspira la tradición de la técnica dan forma a un lenguaje universal. El complejo termal en Vals, una de sus obras más celebradas, es una prueba de ello. Casi al finalizar el diseño del edificio el arquitecto visita los antiguos baños de Estambul, Budapest y Bursa y comenta: "En aquel momento comprendí no sólo de dónde proceden estas imágenes, sino que también forman parte de un legado universal y profundamente arcaico".

Es preocupante que con los avances de las comunicaciones sufrimos de una sobreexposición de información cada vez más lejana de nuestra realidad cotidiana. Con cierto temor he observado verdaderos cultos hacia tendencias que poco tienen que ver con nuestra realidad inmediata al ser extrapoladas de forma literal y que al cabo de un tiempo queda en evidencia su falta de sustancia al no resistir la prueba más dura de la permanencia. Quizás hace falta un acto de humildad para comprender que tras lo que aparentemente resulte poco atractivo e incluso desechable en una primera aproximación, probablemente pueda proporcionarnos las pistas para entender la labor del arquitecto como un fenómeno cultural único y valioso para cada contexto específico.

Albert Tidy

Arquitecto, Universidad de Chile (1992) y Master en Arquitectura, Universidad de Yale (1999). Trabaja entre 1993 y 1996 para Gonzalo Mardones, destacando su participación en los provectos Colegio Nido de Águilas, Showroom Duomo y el Plan General del Museo Interactivo Mirador. Actualmente se desempeña como profesor de Taller en la Universidad de Chile y en la Pontificia Universidad Católica de Chile, compatibilizando la docencia con el trabajo arquitectónico.

\section{La seducción de lo cotidiano}

\section{Mauricio Baros}

No se puede hablar de cotidianeidad sin antes tratar de definirla, o al menos enmarcarla dentro de un contexto. Términos como cotidianeidad, privacidad, colectividad, resultan a veces tan generales y particulares a la vez, que es imposible lograr una definición clara. Generales, porque nos entregan una noción totalmente abierta a todo; lo cotidiano es definido como "lo que ocurre diariamente", "lo usual", lo que es tremendamente vago, en cuanto la existencia es particular y personal a cada individuo lo que nos produce que el término de lo cotidiano se fragmente en miles de pequeñas cotidianeidades personales y particulares de cada uno. Lo que aquí nos interesa, sin embargo, es el lugar en donde ellas suelen encontrarse, en lo que denominamos lugares cotidianos. Lugares que deben su existencia al hecho de que entre los miles de cotidianos particulares que podemos tener, existe por lo menos un grupo de ellos que nos son comunes a un grupo mayor de personas, y estos grupos se encuentran fugazmente por momentos en espacios definidos y determinados para tal efecto. Es acerca de estos espacios de encuentro fugaz de los que queremos hablar aquí. Espacios como el café, la calle, el almacén de la esquina, etc. Lugares de los cuales han derivado muchos otros hoy en día; el café se transforma en cibercafé, la calle en galería comercial, el almacén en supermercado, etc. Hay un cambio de tiempo y de escalas significativo, la velocidad de la mirada del paso es otro, la escala crece considerablemente, pero en el fondo existen ciertos elementos invariantes en estos lugares cotidianos, que son los que queremos tratar a continuación.

... Los seres existen para los otros según el modo como se miran. $Y$ en ese mundo que estaba conociendo, existían varios modos que significaban ver: un mirar al otro sin verlo, un poseer al otro, un devorar al otro, y un apenas estar en el canto y que el otro esté alli también.

Ese estar en el canto es algo propio de lo cotidiano, el vivir en el intervalo entre dos situaciones, entre el espacio de la vida privada y la vida pública. Ese estar en el borde del algo posibilita esa mirada lateral, oblicua, tangencial a la gente y el espacio, puede ser una forma de estar y también de vivir Son intervalos, momentos y, por lo tanto, espacios, espacios laterales, de fuga, espacios de fuga de la mirada y de la propia presencia en el lugar. La silla del café junto a la ventana, la acera, los corredores de una universidad, una esquina. Esta tangencialidad nace de lo cotidiano y a la vez lo condiciona; en el momento que pierde esta lateralidad y pasa a ser punto focal es otra cosa. Lo cotidiano asíse caracteriza por esta situación de un "estar abierto", abierto a la mirada, a la fuga, es un momento en viaje.

Y por ser tan transitoria y fugaz, esta cotidianeidad está sujeta al tiempo, a la hora. Los usos de nuestros cotidianos son muy efímeros durante el día, es decir, podríamos decir, que hay cierto tiempo en cuanto horario para lo cotidiano. As como resulta ser un intervalo entre dos vidas, también es un intervalo entre dos tiempos, un momento robado a la rutina diaria y, por lo tanto, fugaz. Son los minutos robados a una existencia quizás demasiado medida, demasiado normada. Es un burto hecho al tiempo y al espacio, los espacios cotidianos vienen a ser los reductos en donde depositamos el botín de los minutos robados a nuestra propia rutina. $Y$ es un burto compartido, y una complicidad también compartida.

Lo cotidiano posee también como particularidad ese weathearing, ese uso que se hace de un lugar. Existe un compromiso, una cierta complicidad con los lugares cotidianos. Este uso, sin embargo, implica un desgaste. Es aquel roce lateral, aquella marca que dejan los cuerpos al rozarse con un objeto, al ocupar los espacios, cuerpos extranjeros. El cuerpo tiende a hacer suyo lo cotidiano, amoldándolo, y lo cotidiano por su parte tiende a envolver al cuerpo. Este amoldamiento de lo cotidiano no es sino una manera de hacer nuestro ese momento, ese lugar, una manera de poseer; de esta forma se genera una pertenencia extranjera, me pertenece algo que no es mío, y es eso lo que lo hace especial. Es algo personal, mío, pero a la vez de otra persona, privacidades compartidas. Hay una cierta complicidad tremendamente seductora en el uso de los espacios cotidianos.

Lo cotidiano, por su parte, envuelve al cuerpo con sus olores, sabores, etc. En él nosotros somos protagonistas, parte de esa seducción. Porque lo cotidiano implica la presencia y uso humano masivos. Lo cotidiano requiere del "contacto" del día a día, de esa fricción, ese roce diario.

Hay algo tremendamente seductor en lo cotidiano por lo breve de su existencia. Lo cotidiano vive una existencia breve pero intensa.

Esta transitoriedad de los espacios cotidianos obliga a una cierta levedad espacial, si lo pudiésemos así denominar. Levedad entendida como un velo, como una espacialidad fina que se teje sobre una realidad física. Son los usos cotidianos, la intensidad de sus vivencias las que tejen este velo fino sobre un espacio físico generalmente "común", sin atributos. Siendo su único atributo el tener la capacidad de sostener diariamente el velo de cotidianeidad que la cubre. De esta manera hemos visto algunos de los atributos de lo cotidiano, sin siquiera llegar a poder definirlo, porque así como uno de estos atributos es el de la mirada fugaz, también la definición nos resulta esquiva y se nos escapa entre los dedos. Tal vez sea lo propio de lo cotidiano el quedar en ese ámbito que es indefinido pero a la vez tremendamente familiar. ... Lo que tenía el gusto que la lengua tiene en la propia boca. $Y$ la ausencia de tal nombre es como la ausencia de nombre que la lengua tiene en la boca. No era, pues nada más que eso...

Las citas son del libro A Mą̧a no escuro de Clarice Lispector (Ed. Rocco Ltda., Rio de Janeiro, 1998).

Mauricio Baros

Arquitecto, Universidad de Chile (1986). Magister en Arquitectura Pontificia Universidad Católica de Chile (1993). Actualmente es docente de las universidades Católica, de Chile y Central. 